\title{
MAGNESIUM SULFATE AS AN ADJUVANT TO ANESTHESIA IN PATIENTS WITH ARTERIAL HYPERTENSION*
}

\author{
Sanja Vicković ${ }^{1,6}$, Miroslava Pjević ${ }^{1,6}$, Arsen Uvelin ${ }^{2,6}$, Dragana Pap ${ }^{3}$, \\ Dragan Nikolic $c^{4,6}$ and Ivica Lalic ${ }^{5,6}$ \\ ${ }^{1}$ Department of Anesthesiology \& Intensive Care, \\ ${ }^{2}$ Emergency Centre, Clinical Centre of Vojvodina; ${ }^{3}$ Students Health Protection Institute, \\ Department of Laboratory Diagnosis; ${ }^{4}$ Department of Vascular Surgery, \\ ${ }^{5}$ Department of Orthopedic Surgery, Clinical Centre of Vojvodina; \\ ${ }^{6}$ University of Novi Sad, Faculty of Medicine, Novi Sad, Serbia
}

SUMMARY - There is limited evidence showing that elevated arterial blood pressure in surgical patients may be associated with increased perioperative risk; however, cardiovascular instability frequently occurs during anesthesia. The most commonly used anesthetic agents, both intravenous and inhalation ones, produce a decrease in arterial blood pressure. Magnesium, acting as a natural calciumchannel blocker, induces direct and indirect vasodilatation, thus playing a role in the treatment of arterial hypertension. In this research, we assessed the effects of magnesium sulfate on cardiovascular stability in patients undergoing diverse planned surgical procedures (abdominal, orthopedic, urology) under general balanced anesthesia, who were diagnosed with arterial hypertension grade 1 and 2 . The research encompassed 100 patients of both sexes, aged from 20 to 65. Immediately before induction of anesthesia with propofol, the patients in the experimental group (50 study subjects) received $30 \mathrm{mg} /$ $\mathrm{kg}$ bolus dose and magnesium sulfate infusion at $10 \mathrm{mg} / \mathrm{kg} / \mathrm{h}$, whereas the subjects in the control group (50 patients) were administered normal saline. Anesthesia was achieved and maintained with sevoflurane, fentanyl and rocuronium. The hemodynamic variables of mean arterial pressure and heart rate were measured every five minutes, starting immediately before magnesium infusion. Statistical analysis of the categorized values of mean arterial pressure and heart rate revealed a statistically significant between-group difference at $60^{\text {th }}$ and $90^{\text {th }}$ minute of anesthesia. In conclusion, magnesium sulfate as an adjuvant to anesthesia in patients with arterial hypertension reduces hemodynamic changes during anesthesia.

Key words: Magnesium sulfate; Hypertension; Hemodynamics; Heart rate; Adjuvants, pharmaceutical; Anesthesia

\section{Introduction}

Although recent developments in technical and procedural aspects of anesthesiology have allowed substantial advancement of surgery, unavoidable anesthe-

Correspondence to: Arsen Uvelin, $M D, P h D$, Emergency Centre, Clinical Centre of Vojvodina, Hajduk Veljkova 1-10, 21000 Novi Sad, Serbia

E-mail: arsen.uvelin@mf.uns.ac.rs

Received March 11, 2015, accepted February 3, 2016 sia-related risks such as perioperative morbidity and mortality still remain a problem even in the $21^{\text {st }}$ century ${ }^{1}$. Accordingly, anesthesiologist plays an important role as a perioperative physician responsible for preoperative assessment, patient preparation, planning and selection of optimal anesthetic technique, and appropriate pharmacological agents.

\footnotetext{
* This article contains part of the research done for doctoral dissertation by Dr Sanja Vicković.
} 
Preoperative indicators of cardiovascular risk in non-cardiac surgery include ischemic heart disease, congestive heart failure, cerebrovascular disease, preoperative insulin therapy, and preoperative serum creatinine levels above $150 \mu \mathrm{mol} / \mathrm{L}^{2}$. Surgical factors affecting cardiac risks are strongly related to the urgency, extent, type and duration of the procedure itself ${ }^{3}$.

It is believed that $15 \%$ of patients presenting for surgical procedures that require anesthesia suffer from arterial hypertension. Cardiovascular instability during anesthesia is more prevalent in these patients. Arterial hypertension associated with organ failure (ischemic heart disease, heart failure, renal failure) substantially increases the probability of perioperative cardiovascular complications. Establishing the type of hypertension, i.e. whether primary (essential) or secondary, is of great importance for further procedure. Conditions such as pheochromocytoma, hyperaldosteronism and renovascular hypertension require specific individual anesthesiologic approach ${ }^{4}$.

According to the guidelines of the European Society of Hypertension (ESH) and European Society of Cardiology (ESC), blood pressure is defined and classified as follows: optimal (systolic $<120 \mathrm{~mm} \mathrm{Hg}$, diastolic $<80 \mathrm{~mm} \mathrm{Hg}$ ); normal (systolic 120-129 and/or diastolic 80-84); high normal (systolic 130-139 and/or diastolic 85-89); grade 1 hypertension (systolic 140159 and/or diastolic 90-99); grade 2 hypertension (systolic 160-179 and/or diastolic 100-109); grade 3 hypertension (systolic >180 and/or diastolic >110); and isolated systolic hypertension (systolic $>140$, diastolic $<90 \mathrm{~mm} \mathrm{Hg})^{5}$.

Grade 1 and 2 hypertension by itself is not considered a risk factor for the occurrence of perioperative cardiovascular complications. In patients with grade 3 hypertension associated with apparent heart or kidney failure, the surgery should be delayed until reestablishment of normal arterial blood pressure and etiologic examination. If the surgery must be performed without delay, invasive intraoperative monitoring of arterial blood pressure should be provided while limiting oscillations of the mean arterial blood pressure to $20 \%$ of baseline values ${ }^{4}$.

An optimal strategy that would maximally reduce the risks of perioperative cardiovascular complications implicates comprehensive preoperative cardiac evaluation of the patient along with appropriate pharmacological treatment regimen ${ }^{3}$. Patients suffering from arterial hypertension are frequently exposed to extreme hypotension after induction of anesthesia, as well as to hypertensive stress-response to laryngoscopy and intubation, surgical incision and extubation. Postoperatively, inadequate pain relief can induce hypertensive response in such patients. Hypertensive episodes are often associated with arrhythmia and myocardial ischemia. Hypo- as well as hypertension can result in cerebrovascular complications ${ }^{6}$.

Magnesium is of vital importance for human body. The majority of magnesium is absorbed in the small intestine. Kidneys play an important role in maintaining magnesium balance within the body. Administration of diuretics substantially increases magnesium excretion. The metabolism of magnesium is regulated through the action of a variety of hormones. Parathyroid hormone upregulates renal excretion of magnesium and decreases its intestinal absorption. Mineralocorticoids (aldosterone), thyroid hormones and insulin are responsible for increased renal excretion of magnesium, whereas adrenaline is associated with elevation of plasma magnesium levels. Increased serum magnesium concentration (hypermagnesemia) can occur in chronic infectious diseases, diabetic ketoacidosis, Addison's disease, atherosclerosis, and particularly in chronic renal insufficiency. Decreased serum magnesium level (hypomagnesemia) is often associated with enduring diarrhea, prolonged diuretic therapy, malabsorption syndrome, hyperaldosteronism and alcoholism. Hypomagnesemia is a common event in hypokalemic patients. Ionized free magnesium in serum is of crucial biological importance for mediating cellular ion channels and transport mechanisms. Magnesium plays a role in controlling calcium entry into the cells, thus affecting the cardiac smooth muscle tone, i.e. the tone of vascular smooth muscles ${ }^{7}$.

Magnesium is considered the fourth most common cation within the whole of the human body and the second most important intracellular cation. It is a cofactor in the activation of a whole range of enzymes involved in biochemical reactions of protein synthesis. Magnesium manifests antinociceptive effects as a competitive antagonist of $\mathrm{N}$-methyl-D-aspartate receptors. Competing with calcium ions, magnesium inhibits the release of presynaptic acetylcholine, thus enhancing the action of neuromuscular blocking agents. Magnesium sulfate depresses the central nervous system and reduces anesthetic requirements ${ }^{8}$. 
Magnesium is regarded as a natural physiologic calcium antagonist. Patients subjected to major surgical procedure without magnesium supplementation are exposed to an increased risk of hypomagnesemia during the early postoperative period ${ }^{9}$. Magnesium is also used as an effective antiarrhythmic agent ${ }^{10}$. Some in vitro studies demonstrated that magnesium prevented catecholamine release from the adrenal medulla and adrenergic terminals, and produced coronary vasodilatation ${ }^{11}$. Ryu et al. demonstrated that the effects of magnesium sulfate in providing adequately controlled hypotension in patients undergoing ear surgery were the same as those of remifentanil ${ }^{12}$.

Magnesium sulfate is applicable in therapy of hypokalemia, asthmatic attack and for protecting the heart muscle following ischemia ${ }^{13}$. Some recent studies strongly suggest the anti-inflammatory effects of magnesium sulfate ${ }^{14}$.

The concentration of total magnesium in the serum of an adult person ranges between 0.65 and $1.05 \mathrm{mmol} /$ $\mathrm{L}^{7}$. Magnesium preparations are usually well tolerated even if administered at large doses. In healthy individuals, plasma levels of magnesium ranging within the interval of $2-3.5 \mathrm{mmol} / \mathrm{L}$ are considered acceptable ${ }^{15}$.

The aim of this research was to establish the effects of magnesium sulfate on cardiovascular stability in patients suffering from arterial hypertension, who were subjected to non-cardiac surgery (elective abdominal, orthopedic and urology surgical procedures) under general balanced anesthesia.

\section{Patients and Methods}

In this double blind, prospective, randomized and controlled clinical trial, we assessed the effects of magnesium sulfate on cardiovascular stability in patients undergoing diverse planned surgical procedures (abdominal, orthopedic, urology) under general balanced anesthesia, who were diagnosed with grade 1 and 2 arterial hypertension. The research encompassed $100 \mathrm{pa}^{-}$ tients of both sexes, aged from 20 to 65 . Immediately before the induction of anesthesia with propofol $(2 \mathrm{mg} /$ $\mathrm{kg}$ intravenously), the patients received $30 \mathrm{mg} / \mathrm{kg}$ bolus dose and magnesium sulfate infusion at $10 \mathrm{mg} / \mathrm{kg} / \mathrm{h}(\mathrm{M}$ group, $n=50$ patients) or saline placebo (K group, $n=50$ patients). Anesthesia was achieved and maintained with sevoflurane (1-3 vol\%), fentanyl $(5 \mu \mathrm{g} / \mathrm{kg}$ ) and rocuronium $(0.15 \mathrm{mg} / \mathrm{kg}$ every 30 minutes).
Pregnant women, patients with organ failure, patients with elevated potassium and magnesium levels, patients on calcium channel blocker therapy, and patients with AV block, myasthenia gravis or porphyria were not included in the research. Furthermore, patients suffering massive intraoperative blood loss and those treated intraoperatively with antihypertensive drugs, antiarrhythmics or diuretics were excluded from the study.

The hemodynamic parameters of the mean arterial pressure (MAP) and heart rate (HR) were monitored and recorded every five minutes. Baseline MAP had been measured before magnesium intravenous bolus was administered to the patient. Arterial blood pressure was measured noninvasively (Datex-Ohmeda S/5 2008).

All subjects gave their informed consent for participation in this study, approved by the local Ethics Committee.

Differences between the investigated groups were evaluated using Pearson $\chi^{2}$-test, Fisher exact test, and Wilcoxon rank sum test (Mann-Whitney). All hypotheses were tested at the level of statistical significance of 0.05 .

\section{Results}

The study encompassed 100 patients, 49 males and 51 females. Pearson $\chi^{2}$-test found no statistically significant gender-related differences between the groups $\left(\chi^{2}=0.04, d f=1, p=0.84145, p>0.05\right)$. The mean age of the group $\mathrm{K}$ and $\mathrm{M}$ patients was $57.1 \pm 7.96$ and $56.32 \pm 7.89$ years, respectively. Mann-Whitney test demonstrated no statistically significant age differences $(\mathrm{W}=1303, \mathrm{p}=0.71671, \mathrm{p}>0.05)$. Out of $100 \mathrm{pa}-$ tients included in the study, 53 were categorized as American Society of Anesthesiologists (ASA) class II, whereas 47 were classified as ASA III. Pearson $\chi^{2}$-test demonstrated no statistically significant differences according to ASA status $\left(\chi^{2}=1.004, d f=1, p=0.31644\right.$, $\mathrm{p}>0.05)$. All patients included in this study suffered from arterial hypertension. Out of 100 participating patients, 47 had grade I hypertension, whereas $53 \mathrm{pa}-$ tients had grade II hypertension. Pearson $\chi^{2}$-test yielded no statistically significant between-group differences according to the grade of arterial hypertension $\left(\chi^{2}=0.04, d f=1, p=0.8412, p>0.05\right)$. The groups of participants were homogeneous, thus statistical analysis is considered representative. 
Table 1. Preoperative serum magnesium levels

\begin{tabular}{|l|l|l|l|l|}
\hline & $\begin{array}{l}\text { Median } \\
(\mathrm{mmol} / \mathrm{L})\end{array}$ & $\pm \mathrm{SD}$ & Median & Range \\
\hline $\begin{array}{l}\text { Group K } \\
(\mathrm{n}=50)\end{array}$ & 0.82 & 0.12 & 0.86 & $(0.42$ to 0.99$)$ \\
$\begin{array}{l}\text { Group M } \\
(\mathrm{n}=50)\end{array}$ & 0.86 & 0.12 & 0.88 & $(0.56$ to 1.06$)$ \\
\hline
\end{tabular}

Group $\mathrm{K}$ = patients received saline placebo; group $\mathrm{M}=$ patients received $30 \mathrm{mg} / \mathrm{kg}$ bolus dose and magnesium sulfate infusion at 10 $\mathrm{mg} / \mathrm{kg} / \mathrm{h}$

Table 2. Postoperative serum magnesium levels

\begin{tabular}{|l|l|l|l|l|}
\hline & $\begin{array}{l}\text { Median } \\
(\mathrm{mmol} / \mathrm{L})\end{array}$ & $\pm \mathrm{SD}$ & Median & Range \\
\hline $\begin{array}{l}\text { Group K } \\
(\mathrm{n}=50)\end{array}$ & 0.79 & 0.07 & 0.775 & $(0.4$ to 0.9$)$ \\
$\begin{array}{l}\text { Group M } \\
(\mathrm{n}=50)\end{array}$ & 1.36 & 0.74 & 1.14 & $(0.75$ to 3.51$)$ \\
\hline
\end{tabular}

Group $\mathrm{K}$ = patients received saline placebo; group $\mathrm{M}$ = patients received $30 \mathrm{mg} / \mathrm{kg}$ bolus dose and magnesium sulfate infusion at 10 $\mathrm{mg} / \mathrm{kg} / \mathrm{h}$

Preoperative serum levels of magnesium ranged from 0.42 to $0.99 \mathrm{mmol} / \mathrm{L}$ in group $\mathrm{K}$ and from 0.56 to $1.06 \mathrm{mmol} / \mathrm{L}$ in group $\mathrm{M}$ (Table 1 ). Postoperative serum magnesium values ranged from 0.4 to 0.9 $\mathrm{mmol} / \mathrm{L}$ and from 0.75 to $3.51 \mathrm{mmol} / \mathrm{L}$ in group $\mathrm{K}$ and $M$, respectively (Table 2 ).

Intravenous administration of magnesium sulfate bolus dose $(30 \mathrm{mg} / \mathrm{kg})$ resulted in MAP decrease in the majority of participants. After induction in anesthesia, patients from both groups manifested MAP decrease; however, differences between the groups were not statistically significant. An increase in MAP values was recorded after endotracheal intubation in both groups, at a rate of $21 \%$ in group $\mathrm{K}$ and $18 \%$ in group M. In the majority of our patients, endotracheal intubation resulted in HR increase. Median HR increase as related to baseline values was $33 \%$ and $26 \%$ in groups $\mathrm{K}$ and $\mathrm{M}$, respectively. Statistical analysis of categorized values of MAP and HR yielded a statistically significant between-group difference at $60^{\text {th }}$ and $90^{\text {th }}$ minute of anesthesia. MAP values were within the range of hemodynamic stability ( $-20 \%$ to $20 \%$ decline from baseline values) in 21 (42\%) group $\mathrm{K}$ patients and 38 (76\%) group M patients (Fig. 1). HR values were within the interval from $-30 \%$ to $30 \%$ decline from

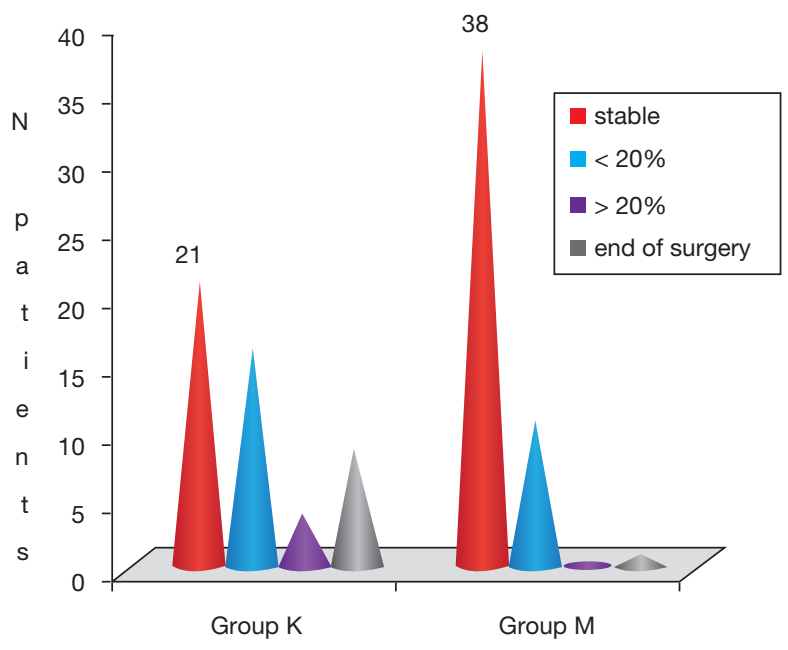

Group $\mathrm{K}=$ patients received saline placebo; group $\mathrm{M}=$ patients received $30 \mathrm{mg} / \mathrm{kg}$ bolus dose and magnesium sulfate infusion at 10 $\mathrm{mg} / \mathrm{kg} / \mathrm{h}$

Fig. 1. Mean arterial pressure (MAP) in $60^{\text {th }}$ minute of anesthesia.

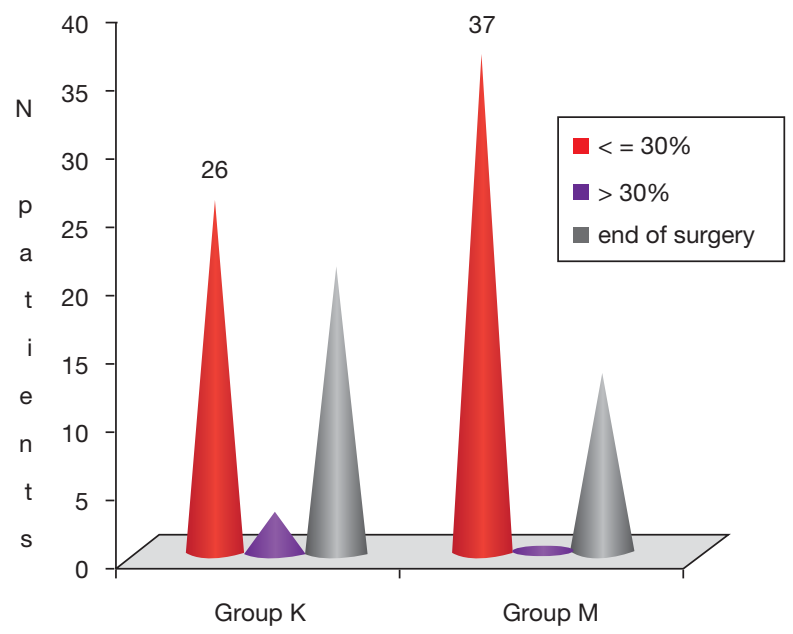

Group $\mathrm{K}=$ patients received saline placebo; group $\mathrm{M}$ = patients received $30 \mathrm{mg} / \mathrm{kg}$ bolus dose and magnesium sulfate infusion at 10 $\mathrm{mg} / \mathrm{kg} / \mathrm{h}$

Fig. 2. Heart rate (HR) in $90^{\text {th }}$ minute of anesthesia.

baseline values in 26 (52\%) group $\mathrm{K}$ patients and 37 (74\%) group M patients (Fig. 2).

According to minimum MAP values, it is apparent that the highest average drop was recorded among participants from group $\mathrm{K}$ with arterial hypertension grade 2. Differences between the group $\mathrm{K}$ arterial hypertension grade 2 and group $\mathrm{M}$ arterial hypertension grade 2 subgroups (K HTA 2 and M HTA 2) were 
Group K HTA 1 Group K HTA 2 Group M HTA 1 Group M HTA 2

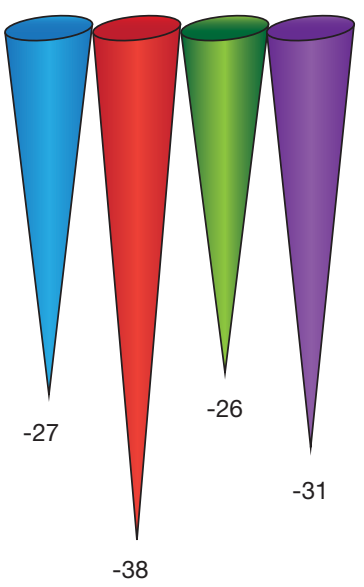

K HTA 1 = patients with arterial hypertension grade 1 receiving saline placebo; K HTA 2 = patients with arterial hypertension grade 2 receiving saline placebo; $\mathrm{M}$ HTA 1 = patients with arterial hypertension grade 1 receiving $30 \mathrm{mg} / \mathrm{kg}$ bolus dose and magnesium sulfate infusion at $10 \mathrm{mg} / \mathrm{kg} / \mathrm{h} ;$ M HTA 2 = patients with arterial hypertension grade 2 receiving $30 \mathrm{mg} / \mathrm{kg}$ bolus dose and magnesium sulfate infusion at $10 \mathrm{mg} / \mathrm{kg} / \mathrm{h}$

Fig. 3. Lowest mean arterial pressure (MAP) compared to baseline MAP (percent change).

statistically significant (Mann-Whitney pair test, $\mathrm{W}=221, \mathrm{p}=0.02033, \mathrm{p}<0.05)$. The participants suffering from grade 2 arterial hypertension who were administered magnesium sulfate manifested a significantly lower MAP drop (Fig. 3).

The median extubation time after cessation of inhalation anesthetic was $7.8 \pm 3.33$ minutes in group $\mathrm{K}$ and $7.1 \pm 2.96$ minutes in group M. This extubation time difference was not statistically significant (MannWhitney test, $\mathrm{W}=1395, \mathrm{p}=0.31108, \mathrm{p}>0.05)$. The mean pain intensity during the immediate postoperative period was assessed using the numerical point scale, which yielded $5.58 \pm 2.89$ points in group $\mathrm{K}$ and $5.02 \pm$ 2.35 in group M. With respect to this parameter, there were no statistically significant differences between the groups (Mann-Whitney test, $\mathrm{W}=1401.5, \mathrm{p}=0.28882$, $\mathrm{p}>0.05)$.

\section{Discussion}

In our research, statistical analysis of categorized MAP values at different time intervals revealed a statistically significant difference between the groups in the $60^{\text {th }}$ minute of anesthesia. At $60^{\text {th }}$ minute of anesthesia, there were no patients with hypertension (pa- tients manifesting MAP increase by more than $20 \%$ as compared with baseline values) in group $\mathrm{M}$. The data obtained data clearly showed that group $\mathrm{M}$ patients manifested better hemodynamic stability than those from group $\mathrm{K}$ at $60^{\text {th }}$ minute of anesthesia. The HR values at $90^{\text {th }}$ minute of anesthesia ranged from $-30 \%$ to $+30 \%$ from baseline values in $52 \%$ of group $\mathrm{K} \mathrm{pa-}$ tients and $74 \%$ of group $M$ patients.

So far, the dosage of magnesium sulfate has been highly variable. Usmani et al. administered magnesium sulfate bolus $50 \mathrm{mg} / \mathrm{kg}$ along with continuous infusion at $15 \mathrm{mg} / \mathrm{kg} / \mathrm{h}$ for pain control ${ }^{16}$. In the study by Seyhan et al., continuous infusion of magnesium sulfate at a dose of $10 \mathrm{mg} / \mathrm{kg} / \mathrm{h}$ was sufficient to substantially reduce the doses of intraoperative anesthetics and neuromuscular blockers, as well as postoperative analge$\operatorname{sics}^{17}$. Niruthisard et al. administered magnesium sulfate infusion to attenuate hypertensive crisis during pheochromocytoma resection in a patient with multiple endocrine neoplasia type $\mathrm{IIa}^{18}$.

A number of studies demonstrated that the administration of magnesium sulfate during anesthesia substantially affected the hemodynamic parameters. Elsharnouby and Elsharnouby applied magnesium sulfate (bolus dose $40 \mathrm{mg} / \mathrm{kg}$, along with i.v. infusion at $15 \mathrm{mg} / \mathrm{kg} / \mathrm{h}$ ) as a technique of hypotensive anesthesia in endoscopic sinus surgery. The authors report statistically significantly lower MAP values in patients having received magnesium ${ }^{19}$.

Altan et al. compared the effects of magnesium sulfate and clonidine on hemodynamic parameters during anesthesia and surgical procedure. MAP values recorded in patients receiving clonidine were significantly lower at all time intervals; however, the difference between the groups was not statistically significant $^{10}$.

Magnesium sulfate was used to prevent fluctuation in arterial blood pressure during surgery for catecholamine-active glomus tumors in two patients. In one patient, sodium nitroprusside failed to provide adequate hemodynamic stability, which was established after the administration of magnesium sulfate. In the second patient, hemodynamic stability was successfully managed using magnesium sulfate as a single agent ${ }^{20}$.

Magnesium sulfate proved effective in patients with subarachnoid hemorrhage due to ruptured aneurysm of cerebral vessels ${ }^{21}$. 
In the present study, cortisol, vasopressin and catecholamine plasma levels were not analyzed, but the interaction of magnesium sulfate and vasopressin is well known because hypersecretion of antidiuretic hormone (vasopressin) results in hypomagnesemia. High concentrations of antidiuretic hormone also caused vasoconstriction and consequential increase of blood pressure. Application of magnesium sulfate reduces the effects of hormone stress response during surgery ${ }^{22,23}$.

Ryu et al. demonstrated the effects of magnesium sulfate in providing adequately controlled hypotension to be the same as those of remifentanil. However, postextubation MAP and HR values were higher in participants administered remifentanil ${ }^{12}$.

The question, whether magnesium sulfate can actually provide hemodynamic stability during anesthesia and under which dosage regimen, requires further research in order to be answered.

In conclusion, magnesium sulfate as an adjuvant to anesthesia in patients with arterial hypertension reduces hemodynamic changes during anesthesia.

\section{References}

1. Fleisher L. Risk of anaesthesia. In: Cucchiara R, Miller E, Reves JG, Roizen M, Savarese J, eds. Anesthesia. Philadelphia, Pennsylvania: Churchill Livingstone; 2000. p. 795-823.

2. Baker B, Jenkins K, Werrett G. Consent and anaesthetic risk. In: Allman KG, Wilson IH, eds. Oxford Handbook of Anaesthesia. Oxford, New York: Oxford University Press; 2006. p. 15-37.

3. Poldermans D et al. Guidelines for pre-operative cardiac risk assessment and perioperative cardiac management in non-cardiac surgery: the Task Force for Preoperative Cardiac Risk Assessment and Perioperative Cardiac Management in Non-cardiac Surgery of the European Society of Cardiology (ESC) and endorsed by the European Society of Anaesthesiology (ESA). Eur J Anaesthesiol. 2010;27:92-137. http://dx.doi: 10.1097/ EJA.0b013e328334c017.

4. Telford R, Murphy P. Cardiovascular disease. In: Allman KG, Wilson IH, eds. Oxford Handbook of Anaesthesia. Oxford, New York: Oxford University Press; 2006. p. 39-76.

5. Mancia G, Backer GD, Dominiczak A, Cifkova R, Fagard R, Germano G. 2007 Guidelines for the management of arterial hypertension. Eur Heart J. 2007;28:1462-536. http://dx.doi: 10.1093/eurheartj/ehm236.

6. Foëx P, Sear JW. The surgical hypertensive patient. Cont Educ Anaesth Crit Care Pain. 2004;5(4):139-43. http://dx. doi: 10.1093/bjaceaccp/mkh039.
7. Čvorišćec D, Čepelak I. Magnezij. In: Čvorišćec D, Čepelak I, eds. Štrausova medicinska biokemija. Zagreb: Medicinska naklada; 2009. p. 79-81. (in Croatian)

8. Cizmeci P, Ozkose Z. Magnesium sulphate as an adjuvant to total intravenous anesthesia in septorhinoplasty: a randomized controlled study. Aesthetic Plast Surg. 2007;31:167-73.http:// dx.doi:10.1007/s00266-006-0194-5.

9. Lysakowski C, Dumont L, Czarnetzki C, Tramer MR. Magnesium as an adjuvant to postoperative analgesia: a systematic review of randomized trials. Anesth Analg. 2007;104(6):15329. http://dx.doi:10.1213/01.ane.0000261250.59984.cd

10. Altan A, Turgut N, Yildiz F, Türkmen A, Üstün H. Effects of magnesium sulphate and clonidine on propofol consumption, haemodynamics and postoperative recovery. $\mathrm{Br} \mathrm{J}$ Anaesth. 2005;94:438-41. http://dx.doi:10.1093/bja/aei070

11. Arar C, Colak A, Alagol A, Uzer SS, Ege T, Turan N. The use of esmolol and magnesium to prevent haemodynamic responses to extubation after coronary artery grafting. Eur J Anaesthesiol. 2007;24:826-31. http://dx.doi:10.1017/S0265021507000865

12. Ryu JH, Sohn IS, Do SH. Controlled hypotension for middle ear surgery: a comparison between remifentanil and magnesium sulphate. Br J Anaesth. 2009;103:490-5. http://dx. doi:10.1093/bja/aep229.

13. Ferasatkish R, Dabbagh A, Alavi M. Effect of magnesium sulphate on extubation time and acute pain in coronary artery bypass surgery. Acta Anaesthesiol Scand. 2008;52:1348-52. http://dx. doi: 10.1111/j.1399-6576.2008.01783.x

14. Lin CY, Tsai PS, Hung YC, Huang CJ. L-type calcium channels are involved in mediating the anti-inflammatory effects of magnesium sulphate. Br J Anaesth. 2010;104(1):44-51. http:// dx. doi:10.1093/bja/aep336.

15. Dube L, Granry JC. The therapeutic use of magnesium in anesthesiology, intensive care and emergency medicine: a review. Can J Anesth. 2003;50:732-46. http://dx. doi:10.1007/BF03 018719

16. Usmani H, Quadir A, Alam M. Evaluation of perioperative magnesium sulphate infusion on postoperative pain and analgesic requirements in patients undergoing upper abdominal surgery. J Anaesth Clin Pharmacol. 2007,23(3):255-8.

17. Seyhan T, Tugrul M, Sungur MO. Effects of three different dose regimens of magnesium on propofol requirements, haemodynamic variables and postoperative pain relief in gynaecological surgery. Br J Anaesth. 2006;96:247-52. http://dx. doi: 10.1093/bja/aei291

18. Niruthisard S, Chatrkaw P, Laornual S. Anesthesia for onestage bilateral pheochromocytoma resection in a patient with MEN type IIa: attenuation of hypertensive crisis by magnesium sulphate. J Med Assoc Thai. 2002;85(1):125-30.

19. Elsharnouby NM, Elsharnouby MM. Magnesium sulphate as a technique of hypotensive anaesthesia. Br J Anaesth. 2006; 96(6):727-31. http://dx.doi:10.1093/bja/ael085

20. Goutcher CM, Cossar DF, Ratnasabapathy U, Burke AM. Magnesium in the management of catecholamine-secreting 
glomus tumours with intracranial extension. Can J Anesth. 2006;53(3):316-21. http://dx. doi: 10.1007/BF03022221

21. Wong GK, Poon WS. Magnesium sulphate in the management of patients with aneurysmal subarachnoid hemorrhage: a randomized, placebo-controlled, dose-adapted trial. Surg Neurol. 2008;69:33-9. http://dx. doi:10.1016/j.surneu.2007.12.029
22. Playford H. Morbid obesity. In: Sladen NR, Coursin BD, Ketzler JT, Playford H, eds. Anaesthesia and Co-Existing Disease. Cambridge: Cambridge University Press; 2007: p. 105-6.

23. Whiteley S. Metabolic and endocrine problems. In: Whiteley S, Bodenham A, Bellamy M, eds. Intensive Care. Edinburgh: Churchill Livingstone; 2010: p. 202-27.

Sažetak

\section{MAGNEZIJ SULFAT KAO ADJUVANS U ANESTEZIJI KOD BOLESNIKA S POVIŠENIM KRVNIM TLAKOM}

\section{S. Vicković, M. Pjević, A. Uvelin, D. Pap, D. Nikolić i I. Lalić}

Postoje određeni dokazi koji ukazuju na postojanje povišenog perioperacijskog rizika kod kirurških bolesnika s povišenim arterijskim tlakom, a kardiocirkulacijska nestabilnost je česta pojava tijekom anestezije. Najčešće upotrebljavani intravenski i inhalacijski anestetici izazivaju snižavanje arterijskog tlaka. Magnezij kao prirodni blokator kalcijevih kanala izaziva vazodilataciju te može imati ulogu u terapiji hipertenzije. U istraživanju su ispitani učinci magnezij sulfata na kardiocirkulacijsku stabilnost kod bolesnika s hipertenzijom prvog i drugog stupnja koji su podvrgnuti različitim elektivnim operacijskim zahvatima (abdominalna, ortopedska kirurgija, urologija) u općoj balansiranoj anesteziji. Studija je obuhvatila sto bolesnika oba spola u dobi od 20 do 65 godina. Neposredno prije intravenskog uvoda u opću anesteziju propofolom bolesnici u eksperimentalnoj skupini dobili su magnezij sulfat u dozi od $30 \mathrm{mg} / \mathrm{kg}$ intravenski, a zatim je infuzija magnezij sulfata nastavljena po stopi od $10 \mathrm{mg} / \mathrm{kg} / \mathrm{h}$, dok su bolesnici u kontrolnoj skupini dobili 0,9\%-tnu otopinu natrij klorida. Anestezija se održavala primjenom sevoflurana i fentanila, a mišićna relaksacija primjenom rokuronija. Hemodinamski parametri, srednji arterijski tlak i srčana frekvencija mjereni su svakih 5 minuta, počevši neposredno prije infuzije magnezij sulfata. Statistička analiza pokazala je statistički značajnu razliku između eksperimentalne i kontrolne skupine u vrijednostima srednjeg arterijskog tlaka i srčane frekvencije u 60. i 90. minuti anestezije. Magnezij sulfat kao adjuvans kod bolesnika s hipertenzijom smanjuje hemodinamske promjene tijekom anestezije.

Ključne riječi: Magnezijev sulfat; Hipertenzija; Hemodinamika; Srčana frekvencija; Adjuvansi, farmakološki; Anestezija 